\title{
Concurrent production of cellulase and xylanase from Trichoderma reesei NCIM 1186: enhancement of production by desirability-based multi-objective method
}

\author{
Preethi Jampala $^{1} \cdot$ Satish Tadikamalla $^{2} \cdot$ M. Preethi $^{1} \cdot$ Swathy Ramanujam $^{1} \cdot$ \\ Kiran Babu Uppuluri ${ }^{1}$ (C)
}

Received: 16 September 2016/ Accepted: 7 January 2017/Published online: 8 April 2017

(c) The Author(s) 2017. This article is an open access publication

\begin{abstract}
Application of multiple response optimizations using desirability function in the production of microbial metabolites improves economy and efficiency. Concurrent production of cellulase and xylanase in Trichoderma reesei NCIM 1186 using an agricultural weed, Prosopis juliflora pods, was studied. The main aim of the study was to optimize significant medium nutrient parameters for maximization of cellulase and xylanase by multi-objective optimization strategy using biomass. Process parameters such as the nutrient concentrations (pods, sucrose, and yeast extract) and $\mathrm{pH}$ were investigated to improve cellulase and xylanase activities by one factor at a time approach, single response optimization and multi-objective optimization. At the corresponding optimized process parameters in single response optimization, the maximum cellulase activity observed was $3055.65 \mathrm{U} / \mathrm{L}$ where xylanase highest activity was $422.16 \mathrm{U} / \mathrm{L}$. Similarly, the maximum xylanase activity, $444.94 \mathrm{U} / \mathrm{L}$, was observed with the highest cellulase activity of $2804.40 \mathrm{U} / \mathrm{L}$. The multiobjective optimization finds a tradeoff between the two objectives and optimal activity values in between the single-objective optima were achieved, 3033.74 and $439.13 \mathrm{U} / \mathrm{L}$ for cellulase and xylanase, respectively.
\end{abstract}

Preethi Jampala and Satish Tadikamalla contributed equally.

Kiran Babu Uppuluri

kinnubio@gmail.com

1 Bioprospecting Laboratory, Department of Biotechnology, School of Chemical and Biotechnology, SASTRA University, Thanjavur, Tamil Nadu 613401, India

2 Andaman and Nicobar Centre for Ocean Science and Technology, ESSO-National Institute of Ocean Technology, Port Blair 744103, India
Keywords Cellulase $\cdot$ Xylanase $\cdot$ Trichoderma reesei . Prosopis juliflora $\cdot$ Multi-objective optimization

\section{Introduction}

Application of biotechnological process to produce biofuels and value-added chemicals from renewable lignocellulosic biomass had received much attention in recent decades (Erickson and Winters 2012). The key step is the depolymerization of biomass polymers into fermentable sugars. The use of acids/alkalies can be cost efficient but they are not convincible due to their operational high temperature and problematic disposal of acid/ alkaline waste. Enzymatic treatment of lignocellulosic biomass offers an efficient and cost-effective hydrolysis at mild conditions. This also avoids additional detoxification steps before successive microbial fermentation. The enzymatic hydrolysis of lignocellulosic biomass typically involves the conversion of cellulose into glucose, and hemicellulose into xylose by cellulase and xylanase, respectively (Zhang et al. 2014). However, enzymatic hydrolysis of lignocelluloses involves high concentrations of both cellulase and xylanase. Interestingly, synergistic effects were reported with cellulases and xylanases which anticipate the fewer enzyme requirements in the simultaneous saccharification of cellulosic biomass (Gonçalves et al. 2015).

Usually cellulase and xylanase were produced and recovered separately from two different fermentation systems. But hemicellulolytic microorganisms such as filamentous fungi produce cellulases and xylanases concurrently with different mechanisms of action (Jun et al. 2011). Trichoderma, Humicola, Penicillium and Aspergillus species are known to produce hemicellulolytic enzymes 
in a single fermentation system (Wen et al. 2005; Olsson et al. 2003; Ahamed and Vermette 2010). Trichoderma reesei is known to secrete large amounts of cellulolytic enzymes and also utilizes a broad range of carbon sources (Jun et al. 2011; Wen et al. 2005; Esterbauer et al. 1991; Olsson et al. 2003; Ahamed and Vermette 2008, 2010; Domingues et al. 2000).

Synthetic medium ought to be replaced with cheaply and easily available substrates to cut down the enzyme production cost (Manivannan and Narendhirakannan 2014; Liming and Xueliang 2004). Agricultural crop residues and forestry waste containing lignocelluloses serve as both inducer and substrate in the enzymes production and offer great productivity (Szengyel et al. 2000; Lo et al. 2010). Many cellulosic materials such as wood, waste paper, fruit pomace, bagasse, wheat straw, corn cob, wheat bran, aspen wood, waste newsprint, and waste paper sludge have been studied as potential substrates for production of cellulase and xylanase by $T$. reesei (Wen et al. 2005; Reczey et al. 1996; Liming and Xueliang 2004). Thus, there is a great interest in the utilization of cellulosic biomass as a major substrate for the fermentation medium. Prosopis juliflora a shrub of semi-arid and tropical part of the world could be used as a fermentative substrate (Shitanda et al. 2014). Due to its high cellulosic content, it offers a very good platform for the growth of microorganisms, especially actinomycetes, and fungi. Recently, we have reported the detailed composition of $P$. juliflora pods (Ramasamy et al. 2014).

Optimization using Response Surface Methodology (RSM) approaches was used to maximize the individual responses of cellulase and xylanase with process variables like carbon source, nitrogen source, $\mathrm{pH}$, temperature and so (Srikanth et al. 2015; Wen et al. 2005; Esterbauer et al. 1991; Olsson et al. 2003; Ahamed and Vermette 2008, 2010; Domingues et al. 2000). But so far there is no report on multi-objective optimization approach to enhance the productivity of cellulase and xylanase simultaneously. Determination of optimal conditions by multi-objective optimization is more effective in certain fermentation systems which yield more than a single response. Especially, the fermentation systems that concurrently produce two products like cellulase and xylanase can be effectively optimized using desirability function at less cost. It also provides more information like the optimal composition of a medium which offers higher yields of desirables than using response surface designs (Kanaga et al. 2016).

In the present work, the multi-objective optimization by desirability function approach was studied using a central composite experimental design (CCD) for obtaining higher cellulase and xylanase from $T$. reesei NCIM1186 in solidliquid fermentation using pods of $P$. juliflora as a major substrate. Assessment of individual and multi-objective optimization analysis was also performed to compare cellulase and xylanase productivity.

\section{Materials and methods}

\section{Microorganism and maintenance}

Trichoderma reesei NCIM 1186 was procured from the National Chemical Laboratory, Pune, India. The organism was cultured and stored on potato dextrose agar (PDA) medium at $4{ }^{\circ} \mathrm{C}$ and was subcultured in regular intervals. Glycerol stocks of $80 \%$ were prepared and stored at $-20{ }^{\circ} \mathrm{C}$ for future use. Sporulation inoculum was prepared by adding two loops full of spores from PDA plates into sabouraud dextrose broth and incubated at $30{ }^{\circ} \mathrm{C}$ in a shaker for three days and stationary for next three days. Sporulation occurs and this is used as inoculum for all the systems. Inoculum size of $2 \% \mathrm{v} / \mathrm{v}$ containing $2 \times 10^{4}$ spores/mL was used.

\section{Preparation of substrate}

Prosopis juliflora pods were collected from the area surrounding SASTRA University campus, Thanjavur, Tamil Nadu, India. Pods were washed under tap water to remove dust and dried under sunlight. Later dried pods were powdered in the grinder and sieved. The particles with the size of $0.42 \mathrm{~mm}$ pods were used in the study (Ramasamy et al. 2014).

\section{Production of cellulase and xylanase from pods containing medium}

Trichoderma reesei $\left(2 \mathrm{~mL}, 2 \times 10^{4}\right.$ spores $\left./ \mathrm{mL}\right)$ was inoculated into $250 \mathrm{~mL}$ Erlenmeyer flask containing $100 \mathrm{~mL}$ sterilized medium (30 g/L pretreated pods and $4 \mathrm{~g} / \mathrm{L}$ calcium carbonate) at $\mathrm{pH} 6.5$ and incubated at $30{ }^{\circ} \mathrm{C}$ for $120 \mathrm{~h}$ in a shaker at $150 \mathrm{rpm}$ (REMI CIS24 plus). After the incubation time, the fermented broth was centrifuged at $10,000 \mathrm{rpm}$ at $4{ }^{\circ} \mathrm{C}$ for $10 \mathrm{~min}$ (REMI C24 plus cooling centrifuge) and enzyme activities were determined in the supernatant.

\section{Enzyme assay}

Cellulase and xylanase activities were assayed by measuring the amount of reducing sugars released from cellulose and xylan, respectively, using dinitro salicylic acid (DNS) assay as described by Ghose et al. (Ghose 1987) and Bailey et al. (Bailey et al. 1992). Briefly, $0.5 \mathrm{~mL}$ of culture supernatant was added to $1 \mathrm{~mL}$ of $0.05 \mathrm{M}$ citrate buffer of $\mathrm{pH}$ 4.8. To this mixture, $0.5 \mathrm{~mL} 1 \% \mathrm{w} / \mathrm{v}$ carboxymethyl 
cellulose (CMC) was added as a substrate for cellulase assay and $0.5 \mathrm{~mL} 1 \% \mathrm{w} / \mathrm{v}$ beech wood xylan was added as a substrate for xylanase assay. All the samples were incubated at $50{ }^{\circ} \mathrm{C}$ for $30 \mathrm{~min}$. To this, $2 \mathrm{~mL}$ of DNS reagent was added, heated in water bath at $90{ }^{\circ} \mathrm{C}$ for $10 \mathrm{~min}$ and cooled immediately. Development of color was visible and the absorbance was measured in a spectrophotometer at $540 \mathrm{~nm}$. Reducing sugar concentration was determined using glucose standard for cellulase activity and xylose standard for xylanase activity. Both cellulase and xylanase activities were reported as U/L. One unit of activity was expressed as the amount of enzyme required to release $1 \mathrm{~mol}$ of reducing sugar/min under assay conditions.

\section{Effect of fermentation parameters on the production of cellulase and xylanase by one factor at a time (OFAT)}

\section{Effect of incubation time, $p H$, and temperature}

To identify the optimum fermentation time, the inoculated medium ( $\mathrm{pH}$ 6.5) was incubated in a shaker (150 rpm) at $30{ }^{\circ} \mathrm{C}$ for 8 days. Samples were withdrawn at every $24 \mathrm{~h}$ and enzyme activities were measured as described above. In this OFAT approach, the optimized value of process parameters will be used for the next parameter optimization. Hence, the optimized time will be used for subsequent studies.

To study the effect of $\mathrm{pH}$ on the enzyme activities, the prepared media were adjusted to different $\mathrm{pH}$ (5.5-8.0) using phosphate buffer or acetate buffer. Media were sterilized, inoculated and incubated, and enzyme activities were measured as described above.

For temperature studies, the inoculated media were incubated at different temperatures $\left(20-45^{\circ} \mathrm{C}\right)$ and enzyme activities were measured as described above.

\section{Effect of pods concentration, supplementary carbon and nitrogen sources}

The effective concentration of pods for the maximum production of cellulase and xylanase by $T$. reesei was determined by preparing the media with different concentrations of pods $(1-6 \% \mathrm{w} / \mathrm{v})$.

To study the effect of supplementary carbon sources, seven different carbon sources viz., glucose, fructose, xylose, sucrose, maltose, carboxymethyl cellulose (CMC) and lactose were chosen and studied at $0.4 \% \mathrm{w} / \mathrm{v}$ level. Similarly for nitrogen sources, eleven different nitrogen sources viz., peptone, urea, yeast extract, meat peptone, ammonium sulfate, ammonium chloride, ammonium persulphate, potassium nitrate, sodium nitrite, ammonium hydrogen carbonate and casein were chosen and studied at
$0.4 \% \mathrm{w} / \mathrm{v}$ level. The selected carbon/nitrogen source was added to the pods containing media.

All the media were sterilized, inoculated and incubated, and enzyme activities were measured as described above.

\section{Optimization of medium composition for the maximum cellulase and xylanase activity by central composite design}

Central composite design (CCD) was adopted for fitting a quadratic surface and to optimize effective parameters and their interactions with 26 numbers of experiments. A regression analysis was performed to model responses, cellulase and xylanase individually. According to CCD, the process variables (4 no.) at five coded levels $(-2,-1,0,1,2)$ were studied with $2^{k}+2 k+n_{0}$ number of treatment combinations, where $k$ is the number of independent variables and $n_{0}$ is the number of repetition of experiments at the centre point. Dependent variables were enzyme activities (cellulase/xylanase), whereas independent variables were pods $(2-6 \% \mathrm{w} / \mathrm{v})$, sucrose $(0-0.8 \% \mathrm{w} / \mathrm{v})$, yeast extract $(0-1.5 \% \mathrm{w} / \mathrm{v})$ and $\mathrm{pH}(5.5-7.5)$. All variable levels $X$ were coded as $X_{i}$ according to the following equation, so that $X_{0}$ corresponded to the central value. These experiments were performed in triplicates, and average cellulase (U/L) and xylanase activity (U/L) were analyzed by multiple regressions through least squares method to fit the Eq. (1).

The coded values of the process parameters are determined by the following equation:

$Y=\beta_{0}+\sum \beta_{i} X_{i}+\sum \beta_{i j} X_{i} X_{j}+\sum \beta_{i j} X_{i}^{2}$

where $Y$ is the predicted yield, and $\beta_{0}, \beta_{\mathrm{i}}$, and $\beta_{i j}$ are regression coefficients of the model. $X_{i}$ and $X_{j}$ represent the independent variables in the coded values. Evaluation of the linear, quadratic and interactive effects of the independent variables on the response was done using the above equation.

\section{Multi-Objective optimization analysis}

In this study, desirability function approach was used to analyze multi-objective optimization for maximization of cellulase and xylanase using Minitab 17.1. The value of each response (cellulase and xylanase) for a given combination of controllable variables was translated to a number between zero and one known as individual desirability. If the maximum value of objective type was obtained, the desirability function would be defined as Eq. (2).

$d= \begin{cases}0 & \text { if } Y<1 \\ \left(\frac{Y-L}{T-L}\right)^{s} & \text { if } L \leq Y \geq T \\ 1 & \text { if } Y>T\end{cases}$ 
where $d$ is the desirability function, $L$ is the lower acceptable value to the response, $T$ is the target value, $Y$ is the response and $s$ is the weight of the response. Thus, when $s=1$ ( $d$ is linear), $s>1$ (high importance specified near the target value), $s<1$ (low importance specified near the target value) (Kanaga et al. 2016).

\section{Models validation}

The confirmatory experiment was performed at optimum levels of parameters for maximization of cellulase and xylanase individually as well as a cumulative manner to validate the developed models and kept other medium components level as mentioned in the production medium composition. All model validation experiments and its analysis were conducted in duplicates and average of the result was reported.

\section{Results and discussion}

\section{Production of cellulase and xylanase}

Cellulosic feedstocks and agricultural waste can be used as good fermentative substrates for the production of biochemicals. $P$. juliflora pods containing medium facilitated the growth and metabolism of $T$. reesei NCIM 1186 and yielded a significant level of cellulase, $1714.83 \pm 30.02 \mathrm{U} /$ $\mathrm{L}$ and xylanase, $209.48 \pm 12.78 \mathrm{U} / \mathrm{L}$ activities. Few studies were conducted for the concurrent production of cellulase and xylanase from $T$. reesei using different lignocellulosic biomass (Table 1). During the $T$. reesei cultivation in lignocellulosic medium, cellulose and xylan act as inducers for cellulase and xylanase activities, respectively. $P$. juliflora pods are rich in cellulose and contain a low level of hemicellulose and xylan (Ramasamy et al. 2014). Thus, pods cellulose in the medium contributed to the maximum production of cellulase and less hemicellulose may be the reason for the fewer xylanase activities (Zhang et al. 2014). Juhasz et al. (2005) observed the low xylanase production even in the absence of xylan (Juhasz et al. 2005). However, it was evident that the simultaneous production of cellulase and xylanase from the medium containing pods from $T$. reesei has shown promising results when compared with the literature. Therefore, this medium and strain could be tapped further to increase the cellulase and xylanase yields.

\section{Effect of fermentation parameters on the production of cellulase and xylanase by one factor at a time (OFAT)}

\section{Effect of incubation time, $\mathrm{pH}$ and temperature}

Effect of time courses, $\mathrm{pH}$ and temperature on cellulase and xylanase production by $T$. reesei in medium containing pods is shown in Fig. 1a. The similar production patterns were observed for both the enzymes but significant variation was noted in enzyme activities. The highest activities were found at $30{ }^{\circ} \mathrm{C}$ temperature, $120 \mathrm{~h}$ of incubation and $6.5 \mathrm{pH}$ for cellulase; and $30{ }^{\circ} \mathrm{C}$ temperature $144 \mathrm{~h}$ of incubation and $7.0 \mathrm{pH}$ for xylanase.

Regulation, expression, and formation of depolymerizing enzymes (cellulase, xylanase) in T. reesei follow parallel pattern through various control mechanisms (Strauss and Kubicek 1990). Cellulase and xylanase activities were observed from the 24th hour and were continuously increased during first 5 days, reached the maximum levels between 4-6 days and then decreased thereafter. Decrease in the enzyme activities commonly noticed with the inactivation of enzyme secretion systems in a stressed fungal metabolism due to the depletion of nutrients in the fermentation medium (Nochur et al. 1993). The highest levels of enzyme activities were measured during 96-144 h. Similar results have been observed for $T$. reese $i$ with various lignocellulosic biomass (Wen et al. 2005; Esterbauer et al. 1991; Olsson et al. 2003; Ahamed and Vermette 2008, 2010; Domingues et al. 2000).

Table 1 Concurrent production of cellulase and xylanase from T. reesei using different lignocellulosic biomass

\begin{tabular}{llll}
\hline Substrate & \multicolumn{2}{l}{ Enzyme activity (U/L) } & References \\
\cline { 2 - 3 } & Cellulase & Xylanase & \\
\hline $\begin{array}{llll}\text { Prosopis juliflora pods } \\
\text { (without optimization) }\end{array}$ & $1714.83 \pm 30.02$ & $226.43 \pm 12.78$ & Present study \\
Switchgrass & 720.00 & & \\
Anaerobically digested manure fiber & 480.00 & 2150.00 & Zhang et al. (2012) \\
Corn Stover & 770.00 & 1940.00 & \\
Water Hyacinth & 2319.00 & 2140.00 & Manivannan and Narendhirakannan (2014) \\
Soybean hulls & 360.00 & 2147.00 & Coffman et al. (2014) \\
Corn stover & 930.00 & 27000.00 & Zhang et al. (2014) \\
\hline
\end{tabular}



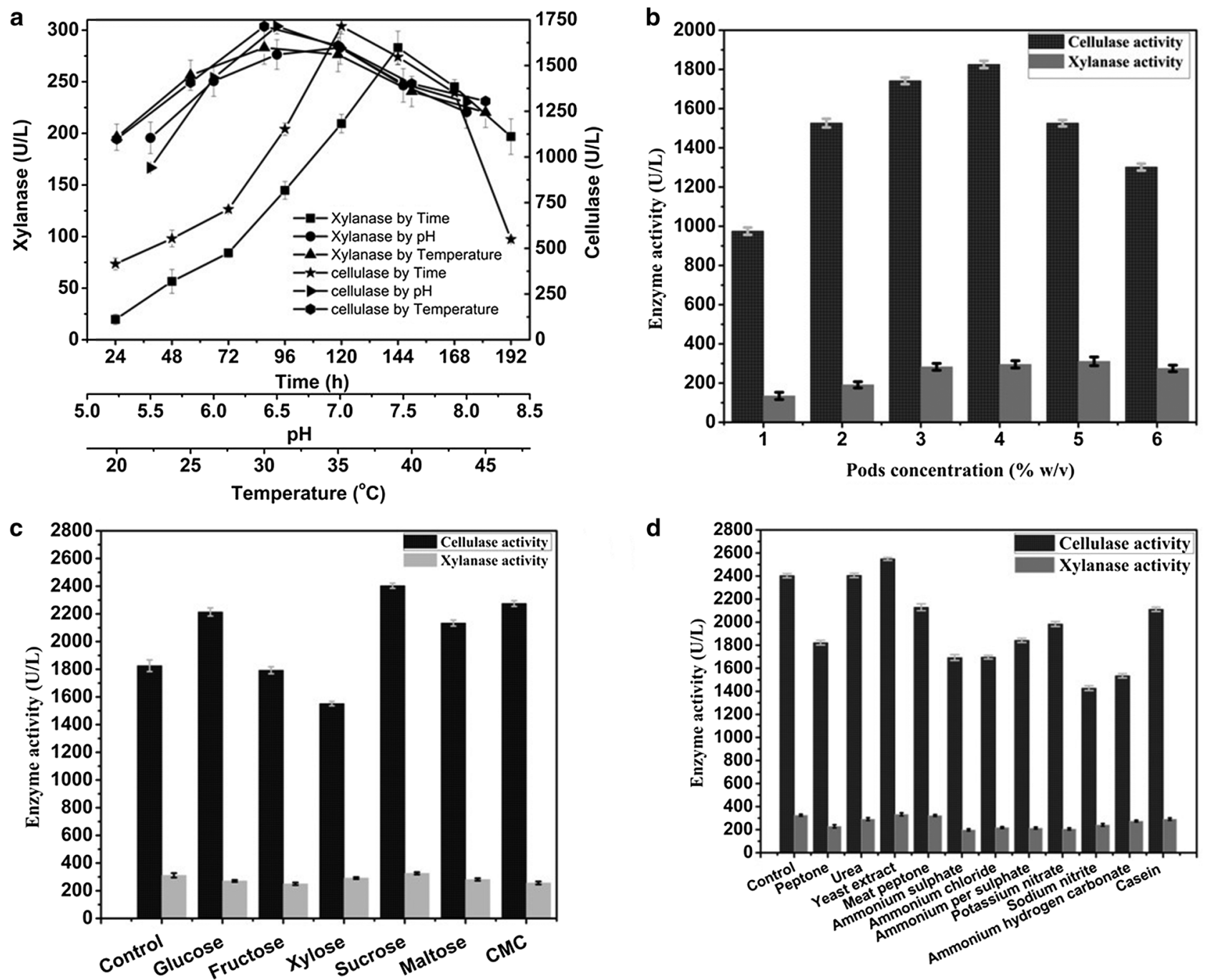

Fig. 1 Effect of process parameters on the production of cellulase and xylanase from $T$. reesei using pods containing the medium: $\mathbf{a}$ effect of time, $\mathrm{pH}$ and Temperature, $\mathbf{b}$ effect of pods concentrations,

Temperature and $\mathrm{pH}$ are two major process parameters of a fermentation system. Together these will play an important role in inducing the morphological changes in microbes and in enzyme secretion. Especially, the $\mathrm{pH}$ change observed during the growth of microbes affects product stability in the medium (Gupta et al. 2003).

Secretion of both the enzymes was observed in the entire range of $\mathrm{pH}$ studied but the highest cellulase and xylanase activities were recorded at slightly acidic conditions $(\mathrm{pH}$ 6.0-7.0). The highest cellulase activity was found at $\mathrm{pH} 7.0$ and xylanase at 6.5 which is consistent with the previous reports (Jun et al. 2011; Zhang et al. 2012). Filamentous fungi secrete extracellular enzymes under highly regulated mechanisms at $\mathrm{pH}$ conditions in which the enzymes are active. In $T$. reesei, ambient $\mathrm{pH}$ was shown to be an important determinant of gene expression for biomass and metabolite production (Häkkinen et al. 2015).

c effect of supplementary carbon sources and d effect of supplementary nitrogen sources

Each Trichoderma species have their own ecological preferences but most of them had grown better under mesophilic conditions (Papavizas 1985). Several studies pertaining to the optimum temperature for cellulase and xylanase production by $T$. reesei have been reported in the range of $25-30{ }^{\circ} \mathrm{C}$. In the present study, high titers of enzyme activities were found in between 25 and $35^{\circ} \mathrm{C}$ (cellulase, $1432.25-1714.83 \mathrm{U} / \mathrm{L}$; xylanase, 256.32 283.04 U/L) with an optimal point at $30{ }^{\circ} \mathrm{C}$, which is in good agreement with the existing literature (Jun et al. 2011; Papavizas 1985; Zhang et al. 2012, 2014).

\section{Effect of pods concentration, supplementary carbon and nitrogen sources}

As aforementioned, the productions of $T$. reesei enzymes are transcriptionally regulated and depend on the availability of 
carbon source (Foreman et al. 2003; Juhasz et al. 2005). However, the range of technically applicable substrates is still limited since most of the pure carbon sources are too expensive for industrial fermentations (Jun et al. 2011). Lignocellulosic biomasses have been widely practiced as potential substrates for the fermentative production of industrial enzymes using microorganisms, especially filamentous fungi. Large quantities of $P$. juliflora (leaves, pods and so forth) waste have been generated and are spreading all over the world. Pods and leaves are unpalatable and indigestible; therefore, it is not suitable for animal feed. To overcome the environmental pollution problems linked with the conventional disposal methods, this waste can be used as substrates in fermentations to produce industrially important products with a great economical advantage (Ramasamy et al. 2014; Jampala et al. 2015).

Recently, we have tested the suitability of pods as a substrate for solid-liquid medium for the production of the cellulase by $T$. reesei, but so far no attempts have been made to optimize the enzyme mixture (Jampala et al. 2015). Our results show that medium containing $4 \% \mathrm{w} / \mathrm{v}$ pods serve as an excellent medium for the production of cellulase, $1825.32 \pm 42.03 \mathrm{U} / \mathrm{L}, 5 \% \mathrm{w} / \mathrm{v}$ pods for xylanase, $311.24 \pm 15.9 \mathrm{U} / \mathrm{L}$ from $T$. reesei (Fig. 1b). Evidently cellulase and xylanase activities were found at even low concentrations of pods, but significant increase (almost $50 \%$ ) in enzyme activities was seen thereafter. Though pods could serve as a medium for the production of enzymes, the supplementary addition of simple carbon source surely induces the initial growth of $T$. reesei and the production of enzymes. Since, induction of cellulolytic enzymes is more dependent on the carbon source than any other components in the medium (Foreman et al. 2003; Kachlishvili et al. 2006).

Almost $15-25 \%$ increased enzyme activities were noted when additional carbon source was given to the medium

Table 2 Central composite design showing real values along with the observed and predicted cellulase and xylanase activities

\begin{tabular}{|c|c|c|c|c|c|c|c|c|}
\hline \multirow[t]{2}{*}{ Run no } & \multirow[t]{2}{*}{ Pods $\% \mathrm{w} / \mathrm{v}$} & \multirow[t]{2}{*}{$\begin{array}{l}\text { Sucrose } \\
\% \mathrm{w} / \mathrm{v}\end{array}$} & \multirow{2}{*}{$\begin{array}{l}\text { Yeast } \\
\text { extract } \\
\% \mathrm{w} / \mathrm{v}\end{array}$} & \multirow[t]{2}{*}{$\mathrm{pH}$} & \multicolumn{2}{|c|}{ Cellulase activity (U/L) } & \multicolumn{2}{|c|}{$\begin{array}{l}\text { Xylanase activity } \\
\text { (U/L) }\end{array}$} \\
\hline & & & & & Observed & Predicted & Observed & Predicted \\
\hline 1. & 3.00 & 0.20 & 0.25 & 6.00 & 1243.69 & 1052.15 & 159.53 & 133.52 \\
\hline 2. & 3.00 & 0.20 & 0.25 & 7.00 & 2017.09 & 2003.62 & 216.24 & 211.90 \\
\hline 3. & 3.00 & 0.20 & 0.75 & 6.00 & 777.81 & 783.39 & 166.47 & 147.68 \\
\hline 4. & 3.00 & 0.20 & 0.75 & 7.00 & 1341.41 & 1417.75 & 121.50 & 141.51 \\
\hline 5. & 3.00 & 0.60 & 0.25 & 6.00 & 584.49 & 650.73 & 136.22 & 123.84 \\
\hline 6. & 3.00 & 0.60 & 0.25 & 7.00 & 967.33 & 838.34 & 171.99 & 139.85 \\
\hline 7. & 3.00 & 0.60 & 0.75 & 6.00 & 618.66 & 721.52 & 78.75 & 98.30 \\
\hline 8. & 3.00 & 0.60 & 0.75 & 7.00 & 577.69 & 592.02 & 21.84 & 29.77 \\
\hline 9. & 5.00 & 0.20 & 0.25 & 6.00 & 634.55 & 683.04 & 165.83 & 188.93 \\
\hline 10. & 5.00 & 0.20 & 0.25 & 7.00 & 1989.32 & 1895.78 & 356.75 & 319.52 \\
\hline 11. & 5.00 & 0.20 & 0.75 & 6.00 & 692.40 & 830.70 & 124.65 & 139.11 \\
\hline 12. & 5.00 & 0.20 & 0.75 & 7.00 & 1729.75 & 1726.33 & 141.76 & 185.16 \\
\hline 13. & 5.00 & 0.60 & 0.25 & 6.00 & 727.56 & 660.54 & 225.06 & 187.38 \\
\hline 14. & 5.00 & 0.60 & 0.25 & 7.00 & 1052.19 & 1109.43 & 205.79 & 255.61 \\
\hline 15. & 5.00 & 0.60 & 0.75 & 6.00 & 1071.45 & 1147.74 & 62.50 & 97.87 \\
\hline 16. & 5.00 & 0.60 & 0.75 & 7.00 & 1078.66 & 1279.52 & 73.21 & 81.55 \\
\hline 17. (C) & 4.00 & 0.40 & 0.50 & 6.50 & 3013.44 & 3013.44 & 410.81 & 434.42 \\
\hline 18. & 2.00 & 0.40 & 0.50 & 6.50 & 498.38 & 568.78 & 218.51 & 248.28 \\
\hline 19. & 6.00 & 0.40 & 0.50 & 6.50 & 1029.70 & 887.17 & 398.58 & 355.47 \\
\hline 20. & 4.00 & 0.00 & 0.50 & 6.50 & 1634.98 & 1687.67 & 172.88 & 172.26 \\
\hline 21. & 4.00 & 0.80 & 0.50 & 6.50 & 964.27 & 839.44 & 71.70 & 58.97 \\
\hline 22. & 4.00 & 0.40 & 0.00 & 6.50 & 1021.04 & 1218.40 & 186.76 & 231.87 \\
\hline 23. & 4.00 & 0.40 & 1.00 & 6.50 & 1389.24 & 1119.74 & 130.42 & 71.97 \\
\hline 24. & 4.00 & 0.40 & 0.50 & 5.50 & 699.46 & 645.93 & 12.06 & 19.93 \\
\hline 25. & 4.00 & 0.40 & 0.50 & 7.50 & 1747.78 & 1729.17 & 103.20 & 81.99 \\
\hline 26. (C) & 4.00 & 0.40 & 0.50 & 6.50 & 3013.44 & 3013.44 & 458.04 & 434.42 \\
\hline
\end{tabular}

$\mathrm{C}$, experiments were conducted with all the central values of the variables 
containing pods. Out of tested carbon sources, sucrose was found to be the best carbon source for both the enzyme productions (cellulase, $2403.29 \pm 18.22 \mathrm{U} / \mathrm{L}$; xylanase, $325.62 \pm 8.52 \mathrm{U} / \mathrm{L}$ ) as shown in Fig. 1c. CMC (cellulase, $2274.73 \mathrm{U} / \mathrm{L}$ ) and glucose (cellulase, 2213.63 U/L) were also shown good cellulase activities. All the tested carbon sources except sucrose have shown a negative impact on the xylanase production. These results suggest that the cellulase and xylanase production by $T$. reese $i$ is carbon source-dependent and that sucrose not only promotes good growth but also efficiently induces the expression of xylanolytic genes (Purkarthofer and Steiner 1995). While sucrose was reported as best supplementary carbon sources for many lignocellulosic biomass (Gautam et al. 2011), CMC (Zhang et al. 2014) and lactose (Jun et al. 2011) also found to be effective for the cellulolytic enzymes by $T$. reesei.

Nature of nitrogen source is one of the potent nutritional factors for regulating the depolymerizing enzymes by filamentous fungi (Sun et al. 2004). The effect of type of nitrogen source depends not only on the fungi physiology but also on the cultivation medium (Kachlishvili et al. 2006). The supplementation of high concentration of organic nitrogen to lignocellulosic medium stimulates the production of cellulolytic enzymes (Kapich et al. 2004). In the present study, 15-25\% incremental enzyme activities were recorded when additional nitrogen sources were added to the medium containing pods (Fig. 1d) and the highest enzyme activities were found with yeast extract (cellulase, $\quad 2548.91 \pm 22.55 \mathrm{U} / \mathrm{L} ; \quad$ xylanase, $333.38 \pm 12.54 \mathrm{U} / \mathrm{L})$. Peptone addition also produced good enzyme activities (cellulase, $2129.13 \pm 28.92 \mathrm{U} / \mathrm{L}$; xylanase, $323.07 \pm 7.48 \mathrm{U} / \mathrm{L}$ ). Gautam et al. 2001 also reported the yeast extract and peptone as better nitrogen sources for the production of these enzymes from $T$. reesei.

\section{Optimization of medium composition for the maximum cellulase and xylanase activity by central composite design (CCD)}

With the CCD experimental results, the multiple regression analysis was performed to determine the relationship between tested parameters [Pods $(\mathrm{P})$, sucrose $(\mathrm{S})$, yeast extract (YE) and $\mathrm{pH}$ ] with measured responses (cellulase and xylanase activities) (Table 2). The significant variation in the activities was observed with the enzymes, cellulase (498.37-3013.45 U/L) and xylanase (2.84-458.03 U/L) indicating the dominant role of selected variables and their concentrations on enzyme production by $T$. reesei NCIM 1186. The low percentage of variation between the

Table 3 Analysis of variance and model coefficient estimate by multiple regression analysis for cellulase and xylanase activities

\begin{tabular}{|c|c|c|c|c|c|c|c|c|}
\hline & \multicolumn{2}{|l|}{ Coeff. } & \multicolumn{2}{|l|}{ Effect } & \multicolumn{2}{|l|}{$t$} & \multicolumn{2}{|l|}{$p$} \\
\hline & Cellulase & Xylanase & Cellulase & Xylanase & Cellulase & Xylanase & Cellulase & Xylanase \\
\hline Mean/interaction & 3013.44 & 434.42 & 3013.44 & 434.42 & 25.098600 & 13.645040 & 0.000000 & 0.000000 \\
\hline $\mathrm{P}$ & 79.60 & 26.78 & 159.20 & 53.59 & 2.296600 & 2.915770 & 0.042286 & 0.014043 \\
\hline $\mathrm{P} * \mathrm{P}$ & -571.37 & -33.14 & -1142.73 & -66.27 & -14.058600 & -3.074850 & 0.000000 & 0.010568 \\
\hline$S$ & -212.06 & -28.32 & -424.12 & -56.64 & -6.118400 & -3.081600 & 0.000075 & 0.010441 \\
\hline $\mathrm{S} * \mathrm{~S}$ & -437.47 & -79.70 & -874.94 & -159.40 & -10.764100 & -7.395490 & 0.000000 & 0.000014 \\
\hline YE & -24.67 & -39.98 & -49.33 & -79.95 & -0.711700 & -4.349550 & 0.491489 & 0.001156 \\
\hline YE*YE & -461.09 & -70.63 & -922.19 & -141.25 & -11.345300 & -6.553420 & 0.000000 & 0.000041 \\
\hline $\mathrm{pH}$ & 270.81 & 15.51 & 541.62 & 31.03 & 7.813500 & 1.688070 & 0.000008 & 0.119511 \\
\hline $\mathrm{pH}^{*} \mathrm{pH}$ & -456.47 & -95.87 & -912.94 & -191.73 & -11.231600 & -8.895430 & 0.000000 & 0.000002 \\
\hline $\mathrm{P} * \mathrm{~S}$ & 94.73 & 2.03 & 189.46 & 4.06 & 2.231600 & 0.180510 & 0.047393 & 0.860034 \\
\hline $\mathrm{P} * \mathrm{YE}$ & 104.10 & -15.99 & 208.21 & -31.98 & 2.452500 & -1.420820 & 0.032105 & 0.183090 \\
\hline $\mathrm{P}^{*} \mathrm{pH}$ & 65.32 & 13.05 & 130.64 & 26.11 & 1.538700 & 1.159740 & 0.152122 & 0.270707 \\
\hline $\mathrm{S} * \mathrm{YE}$ & 84.89 & -9.92 & 169.77 & -19.85 & 1.999700 & -0.881680 & 0.070839 & 0.396809 \\
\hline $\mathrm{S}^{*} \mathrm{pH}$ & -190.96 & -15.59 & -381.93 & -31.18 & -4.498700 & -1.385170 & 0.000903 & 0.193446 \\
\hline YE*pH & -79.28 & -21.13 & -158.56 & -42.27 & -1.867600 & -1.877790 & 0.088670 & 0.087161 \\
\hline \multicolumn{9}{|l|}{ Error } \\
\hline \multicolumn{9}{|l|}{ Total SS } \\
\hline$R^{2}$ & 0.97292 & 0.93331 & & & & & & \\
\hline Adj $R^{2}$ & 0.93846 & 0.84843 & & & & & & \\
\hline
\end{tabular}

OFAT one factor at a time, $C C D$ central composite design, $P$ pods concentration $(\% \mathrm{w} / \mathrm{v}), S$ sucrose concentration $(\% \mathrm{w} / \mathrm{v}), Y E$ yeast extract concentration $(\% \mathrm{w} / \mathrm{v})$

Significant variables were highlighted with italics 
observed and predicted values indicates the accuracy of the experiment. The regression coefficients were calculated and data were fitted to second-order polynomial equations for a respective response. The following regression equations demonstrate an empirical relationship between the selected parameters in real values and enzyme activities.

$$
\begin{aligned}
Y_{\text {cellulase }(\mathrm{U} / \mathrm{L})=} & 3013.44+79.60[\mathrm{P}]-571.37[\mathrm{P}] *[\mathrm{P}] \\
& -212.06[\mathrm{~S}]-437.47[\mathrm{~S}] *[\mathrm{~S}] \\
& -461.09[\mathrm{YE}] *[\mathrm{YE}]+270.81[\mathrm{pH}] \\
& -456.47[\mathrm{pH}] \\
& *[\mathrm{pH}]+94.72[\mathrm{P}] *[\mathrm{~S}] \\
& +104.10[\mathrm{P}] *[\mathrm{YE}]-190.96[\mathrm{~S}] *[\mathrm{pH}] \\
Y_{\text {xylanase }(\mathrm{U} / \mathrm{L})}= & 434.42+26.80[\mathrm{P}]-33.14[\mathrm{P}] *[\mathrm{P}] \\
& -28.32[\mathrm{~S}]-79.70[\mathrm{~S}] *[\mathrm{~S}]-39.98[\mathrm{YE}] \\
& -70.63[\mathrm{YE}] *[\mathrm{YE}]-95.87[\mathrm{pH}] *[\mathrm{pH}]
\end{aligned}
$$

The best levels of the selected significant variables were determined for measured experimental responses. Quadratic regression models were developed for cellulase and xylanase using the analysis of variance (ANOVA)
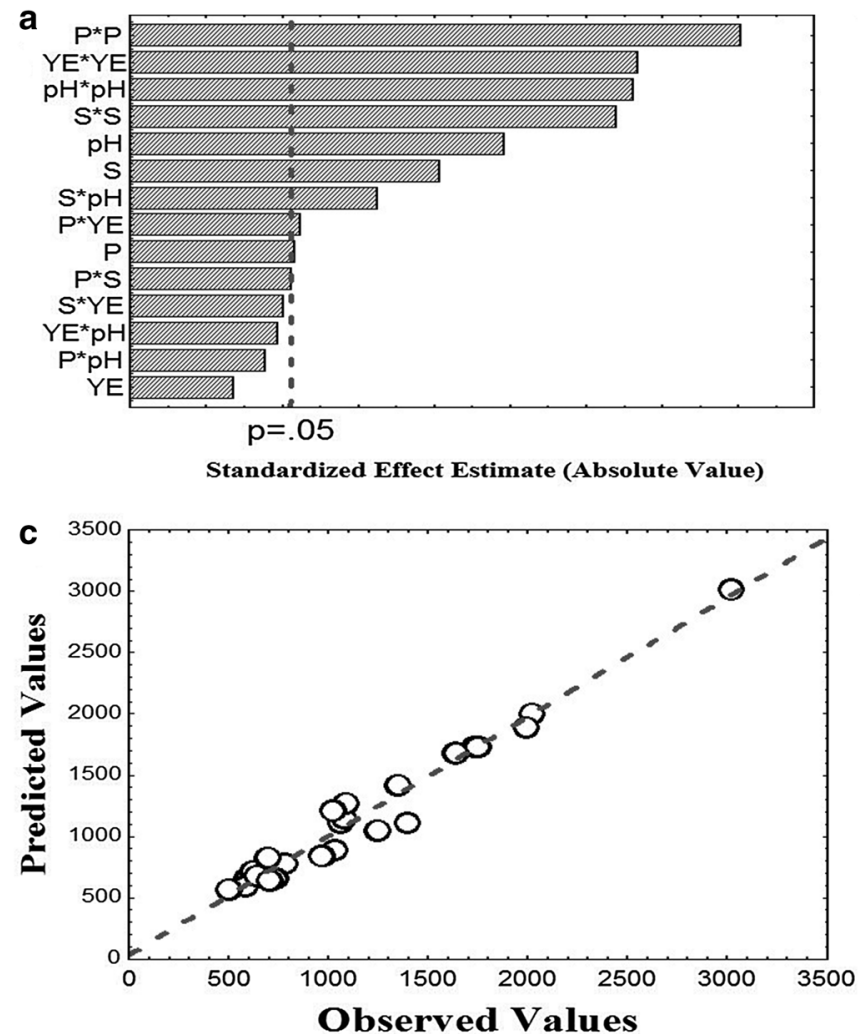

(Table 3). The collective effects of all variables for the developed models were contributed to maximizing the cellulase and xylanase activities. The regression coefficients $\left(R^{2}\right)$ were 0.97 and 0.93 for cellulase and xylanase, respectively, indicating that only $2.7 \%$ (cellulase) and $6.67 \%$ (xylanase) of the variability in the response could not be explained by the model. The high value of adjusted $R^{2}$ values $(0.94$ and 0.85$)$ also suggested the higher significance of models. The goodness of fit for the individual models also indicated that these models for measured cellulase and xylanase were attributed to the tested parameters. The coefficients were selected based on their corresponding $t$ and $p$ values (Table 3 ). The overall $p$ value of the model is $<0.05$ for both the enzymes and the $F$ value is 197.64 (cellulase), 79.13 (xylanase) (model $F$ value $>p$ value), implying that the model is significant. Coefficients which have a low $p$ value and high $F$ value are considered as significant terms. From the regression analysis, all the quadratic terms of tested variables $(\mathrm{P}, \mathrm{S}$, $\mathrm{YE}$, and $\mathrm{pH}$ ) and linear term of pods and sucrose for both the enzyme activities (cellulase and xylanase) were indicated for their high significance on the basis of their $p$ values. Linear terms of $\mathrm{pH}$ on cellulase and yeast extract on xylanase have also shown a significant impact. Interactive terms of $[\mathrm{P}]^{*}[\mathrm{~S}],[\mathrm{P}] *[\mathrm{YE}]$ and $[\mathrm{S}]^{*}[\mathrm{pH}]$ were
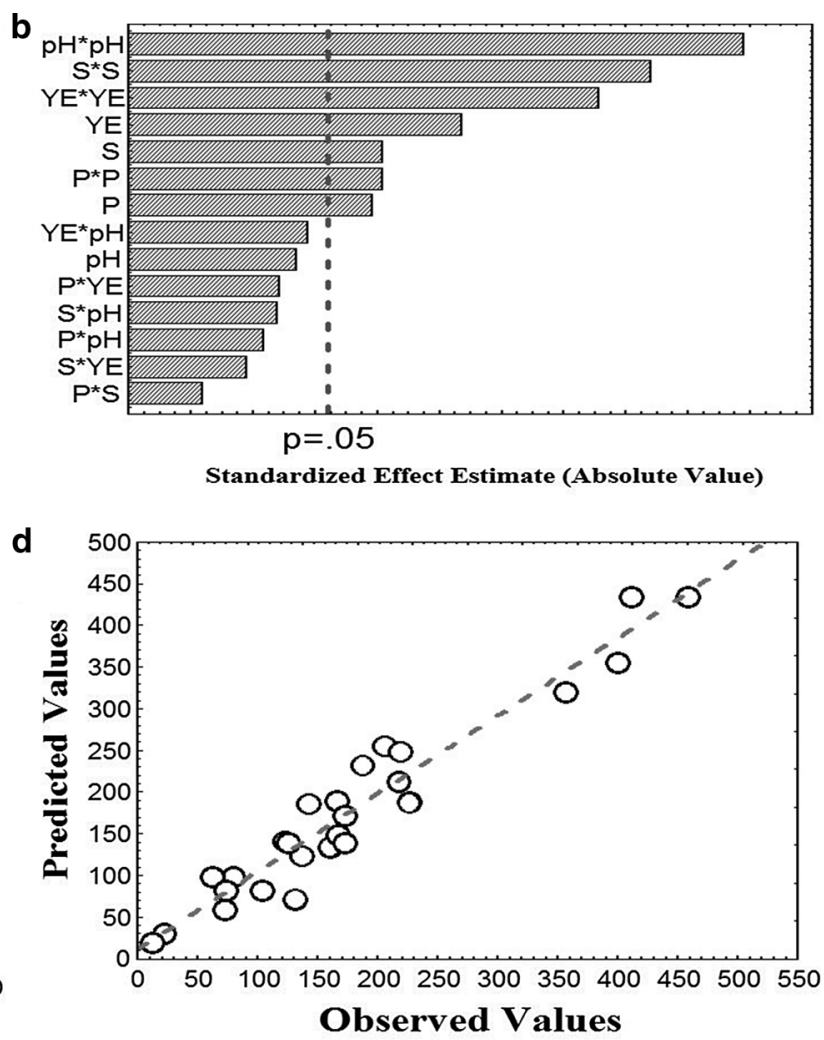

Fig. 2 a, b Pareto chart of effects on cellulase and xylanase activity, respectively, for CCD $(p=0.05)$; c, d Correlation between the experimental and predicted cellulase (U/L) and xylanase activity (U/L) 
highly significant for cellulase activities but no interactive terms are shown significant impact on xylanase activity. Individual significance rankings of linear terms, square terms and interactive terms of variables on cellulase (Fig. 2a) and xylanase (Fig. 2b) were shown in Pareto chart. The correlation plots (Fig. 2c, d) obtained also indicated that the obtained regression model gave a good explanation of the relationship between the independent and response variables. This also indicates an excellent prediction of the response along with parameters value and competence of the developed quadratic models. In the present experiment, the coefficient of variance $(\mathrm{CV})$ was $10.30 \%$ cellulase and $4.13 \%$ xylanase, which implies good precision and reliability.

The regression equations (Eqs. 3 and 4) were used to generate $3 \mathrm{D}$ and $2 \mathrm{D}$ surface $\&$ contour plots, respectively (Figs. 3,4). Using the drawn surface and contour plots interactions, selected variables at different conditions were evaluated. All contours were circular or elliptical in nature, indicating that all selected parameters were independent of each other. Figure $3 \mathrm{a}-\mathrm{c}$ depicts the interaction of pods with other selected variables on cellulase production and it shows that pods concentration was independent of the $\mathrm{pH}$ and slightly dependent on the supplementary carbon and nitrogen sources. Figure 3a, d, e represents the interaction of sucrose with other selected variables on cellulase production. In both Fig. 3a, e, the contours were slightly inclined towards pods and $\mathrm{pH}$ indicating that sucrose concentration has a slight influence on the pods concentration and $\mathrm{pH}$ of the medium. Figure $3 b$, d, f represents the yeast extract interaction on the other variables for the cellulase production. Yeast extract has a slight influence on the pods concentration and $\mathrm{pH}$ of the medium. Similarly, the xylanase activity 3D and contour plots were observed (Fig. 4a-e). The dependency of pods concentration on the supplementary nutritional source can be clearly seen. Influence of selected variables and their interactions also can be determined from the $\mathrm{p}$ values (Table 3 ). Pods in the range of 3-5\% w/v; sucrose, $0.2-0.6 \% \mathrm{w} / \mathrm{v}$; yeast extract, $0.4-1 \% \mathrm{w} / \mathrm{v}$; and $\mathrm{pH}, 6.2-6.8$ were effective for both cellulase and xylanase production.

The real concentration of parameters was used into the corresponding regression equations (Eqs. 3 and 4) to predict the maximum output for both the enzyme activities. The maximum cellulase activity (3102.24 U/L) was predicted with the optimized medium components, pods a

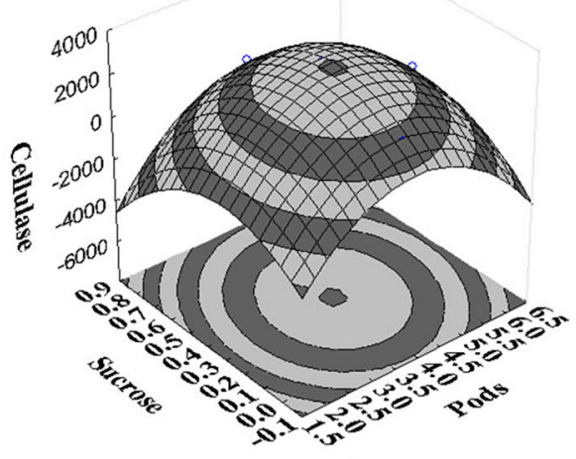

d

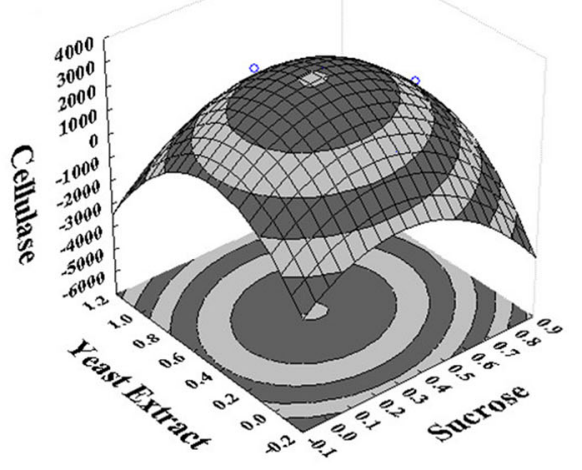

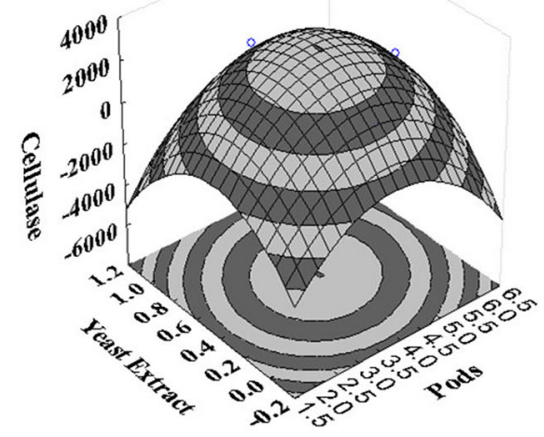

e

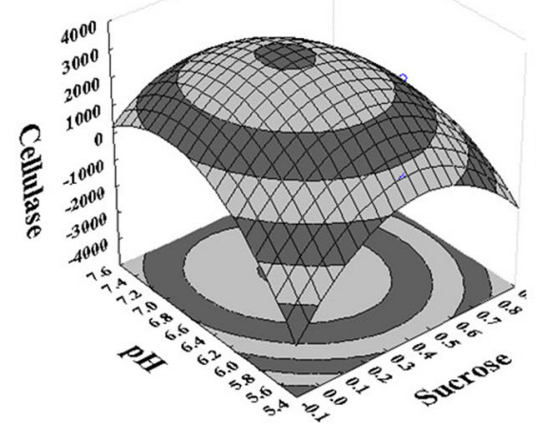

C

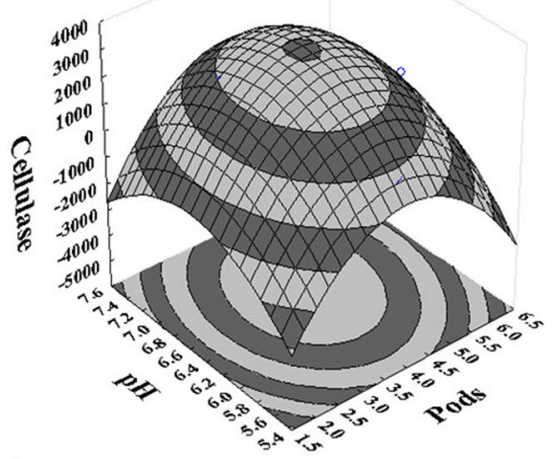

f

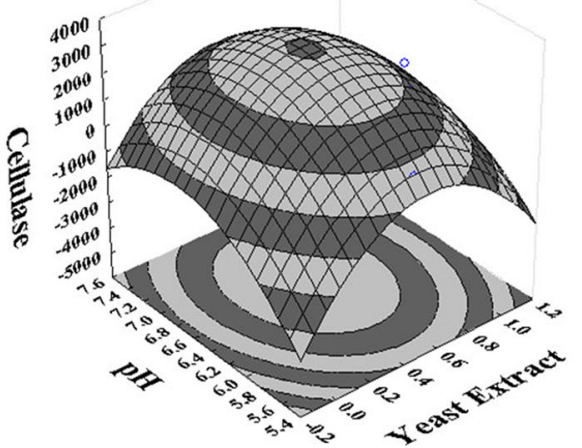

Fig. 3 Surface and contour plots of the selected parameters interaction on cellulase activity (U/L): a pods concentration (\% w/v) with sucrose concentration $(\% \mathrm{w} / \mathrm{v})$, b pods concentration $(\% \mathrm{w} / \mathrm{v})$ with yeast extract concentration $(\% \mathrm{w} / \mathrm{v})$, c pods concentration $(\% \mathrm{w} / \mathrm{v})$ with $\mathrm{pH}$, d sucrose concentration $(\%$ w/v) with yeast extract concentration $(\% \mathrm{w} / \mathrm{v})$, e sucrose concentration $(\% \mathrm{w} / \mathrm{v})$ with $\mathrm{pH}$, f yeast extract concentration $(\% \mathrm{w} / \mathrm{v})$ with $\mathrm{pH}$ 
a

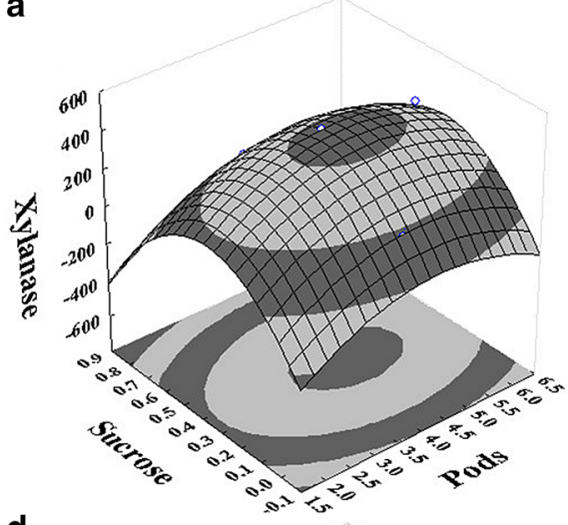

d

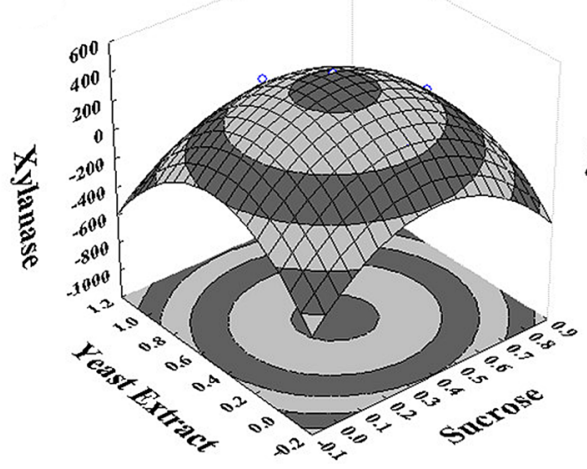

b

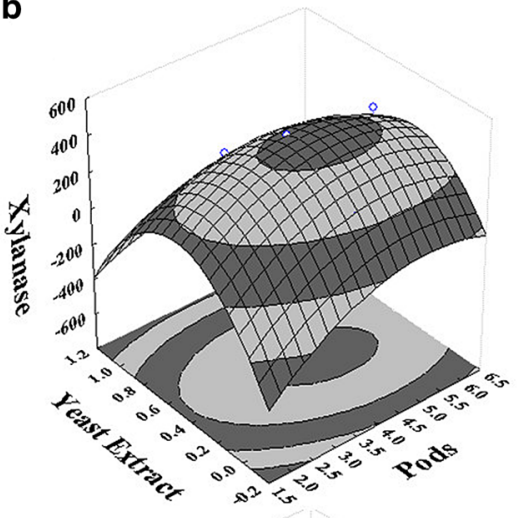

e

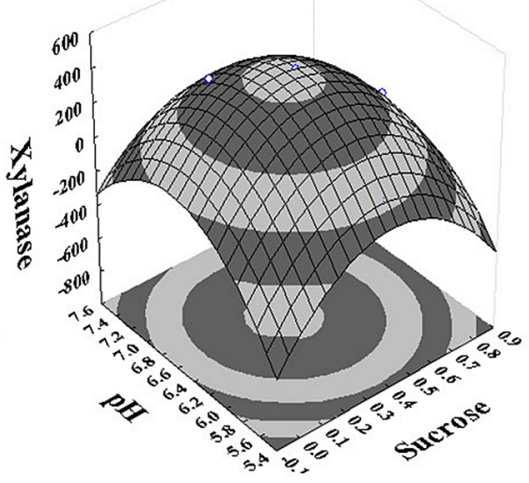

c

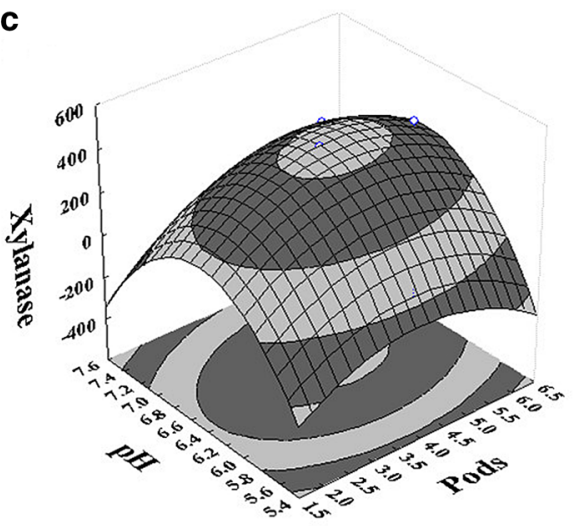

f

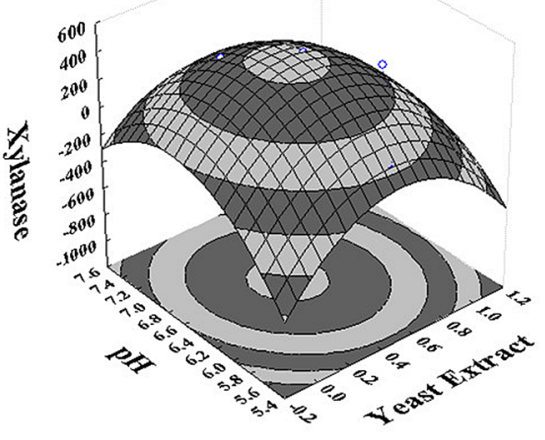

Fig. 4 Surface and contour plots of the selected parameters interaction on xylanase activity (U/L): a pods concentration $(\% \mathrm{w} / \mathrm{v})$ with sucrose concentration $(\% \mathrm{w} / \mathrm{v})$, b pods concentration $(\% \mathrm{w} / \mathrm{v})$ with yeast extract concentration $(\% \mathrm{w} / \mathrm{v})$, c pods concentration $(\% \mathrm{w} / \mathrm{v})$

$30.18 \mathrm{~g} / \mathrm{L}$, sucrose $2.34 \mathrm{~g} / \mathrm{L}$, yeast extract $12.93 \mathrm{~g} / \mathrm{L}$ and pH 6.5 using $T$. reesei NCIM 1186 where xylanase highest activity was $435.21 \mathrm{U} / \mathrm{L}$. Similarly, the maximum xylanase activity (452.12 U/L) was predicted with medium containing pods $36.4 \mathrm{~g} / \mathrm{L}$, sucrose $3.48 \mathrm{~g} / \mathrm{L}$, yeast extract $6.56 \mathrm{~g} / \mathrm{L}$ and $\mathrm{pH} 6.42$ using $T$. reesei NCIM 1186 with highest cellulase activity of $2905.41 \mathrm{U} / \mathrm{L}$ (Table 4). Manivannan and Narendhirakannan (2014) applied a BoxBehnken design to optimize carbon (water hyacinth and xylose) and nitrogen (yeast extract and peptone) sources for the enhanced co-production of cellulase $(23.19 \mathrm{IU} / \mathrm{ml})$ and xylanase $(21.47 \mathrm{IU} / \mathrm{ml})$ by $T$. reesei (Manivannan and Narendhirakannan 2014).

\section{Multi-Objective optimization analysis}

The multi-objective optimization was performed using desirability function to find out the optimal process parameters that do not adversely affect production of one enzyme type in favor of another. Thus, the optimal tradeoff between production of cellulase and xylanase was achieved (Fig. 5). Results were compared with that of single response variable optimization. The maximum predicted with $\mathrm{pH}$, d sucrose concentration (\% w/v) with yeast extract concentration $(\% \mathrm{w} / \mathrm{v})$, e sucrose concentration $(\% \mathrm{w} / \mathrm{v})$ with $\mathrm{pH}$, f yeast extract concentration $(\% \mathrm{w} / \mathrm{v})$ with $\mathrm{pH}$

responses obtained by multi-response optimization were cellulase, $3078.13 \mathrm{U} / \mathrm{L}$ and xylanase, $445.53 \mathrm{U} / \mathrm{L}$ at an optimum level of variables (pods, $41.14 \mathrm{~g} / \mathrm{L}$; sucrose, $3.55 \mathrm{~g} / \mathrm{L}$; yeast extract, $4.54 \mathrm{~g} / \mathrm{L} ; \mathrm{pH}$ 6.6). The optimal enzyme activities obtained from the multi-objective optimization were found to be slightly lower than single response optimized values. However, 20.7 and 33.6\% higher value of corresponding cellulase activity and xylanase activities were observed in multi-objective response optimization than one factor at a time optimization.

The contour surfaces of different responses from important parameters level value can be overlaid and provide the feasible experimental region to fulfill the condition for maximizing the responses altogether. Hence, the overlaid contour plot can be applied to visually elucidate the relationships between the two control factors and two response variables, as shown in Fig. 6. Figure 6a-f corresponds to the overlaid contour diagram for cellulase and xylanase activities from $T$. reesei NCIM 1186 overlapped using Eqs. $(3,4)$ to represent the optimal experimental region of selected medium components. Although the overlaid contour plot can roughly determine the optimal region for multiple response variables, it is limited to two 
Table 4 Comparison of cellulase and xylanase activities of initial, individual and multi-objective optimized medium

\begin{tabular}{|c|c|c|c|c|c|c|c|c|}
\hline \multirow[t]{3}{*}{ Optimization method } & \multicolumn{4}{|l|}{ Conditions } & \multicolumn{4}{|c|}{ Enzyme activity } \\
\hline & \multirow[t]{2}{*}{ Pods $(\% \mathrm{w} / \mathrm{v})$} & \multirow[t]{2}{*}{ Sucrose $(\% \mathrm{w} / \mathrm{v})$} & \multirow[t]{2}{*}{ Yeast extract $(\% \mathrm{w} / \mathrm{v})$} & \multirow[t]{2}{*}{$\mathrm{pH}$} & \multicolumn{2}{|c|}{ Cellulase (U/L) } & \multicolumn{2}{|c|}{ Xylanase (U/L) } \\
\hline & & & & & Predicted & observed & Predicted & observed \\
\hline OFAT for cellulase & 4.00 & 0.30 & 0.50 & 6.50 & - & 2548.91 & - & - \\
\hline OFAT for xylanase & 5.00 & 0.40 & 0.40 & 7.00 & - & - & - & 333.38 \\
\hline CCD for cellulase & 4.05 & 0.33 & 0.47 & 6.60 & 3102.24 & 3055.65 & 435.21 & 422.16 \\
\hline CCD for xylanase & 4.50 & 0.36 & 0.41 & 6.50 & 2905.41 & 2804.40 & 452.12 & 444.94 \\
\hline Multi-objective & 4.14 & 0.35 & 0.45 & 6.60 & 3078.13 & 3033.74 & 445.53 & 439.13 \\
\hline
\end{tabular}

OFAT one factor at a time, $C C D$ central composite design

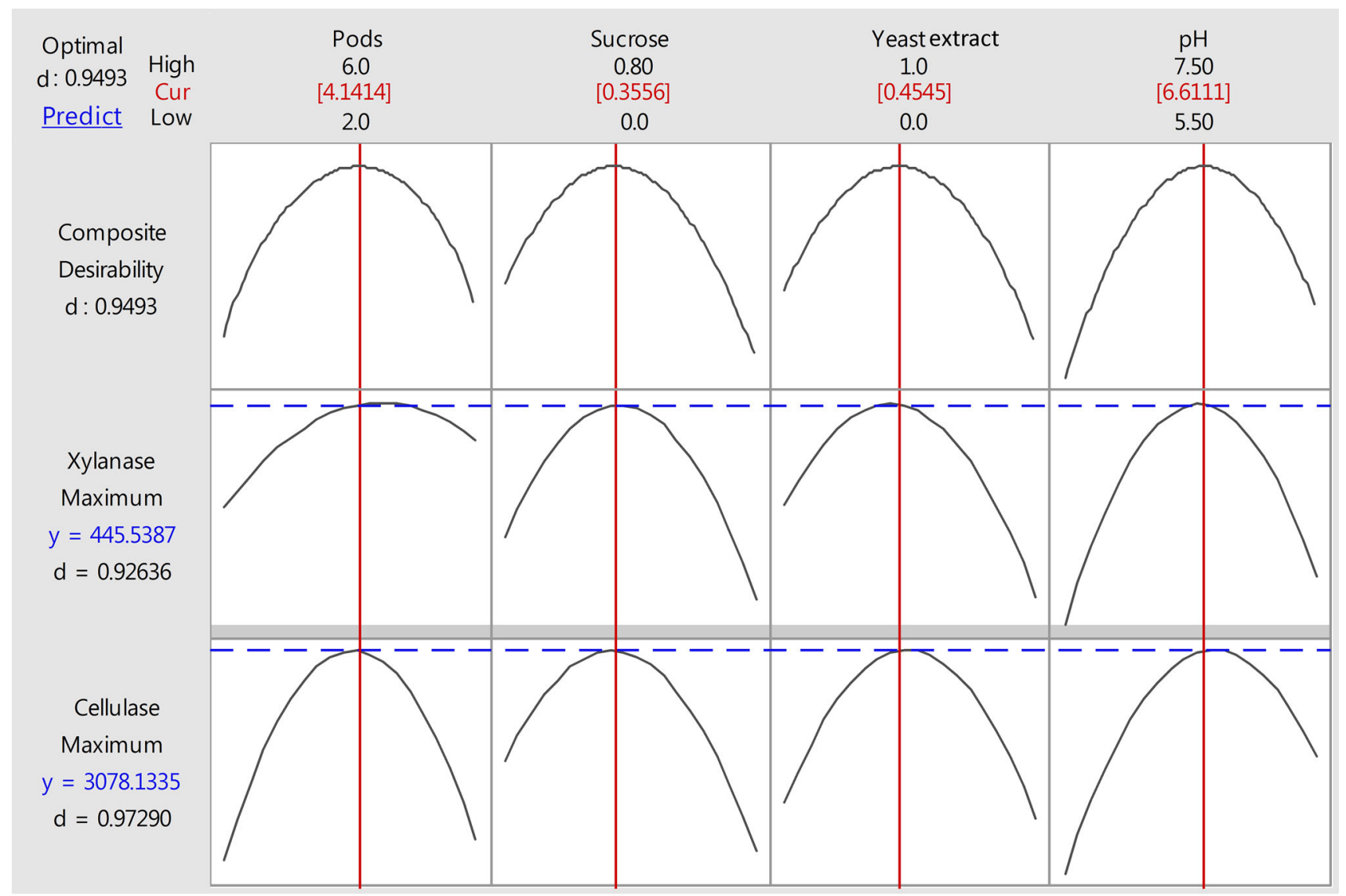

Fig. 5 Multi-objective optimization conditions to maximize production of cellulase and xylanase

experimental factors. White region in the overlaid contour diagram indicates the feasible area for maximum values for responses (cellulase and xylanase) under multi-objective optimized conditions. To the best of our knowledge, this is the first report on the multi-objective optimization for cellulase and xylanase.

\section{Validation of models}

To validate the developed models, experiments were performed using modified production media composition with optimal levels of selected parameters while other media components concentration remains the same. Maximization of single responses for $T$. reesei NCIM 1186, the cellulase and xylanase activity was found to be $3055.65 \pm 24.23$ and $422 \pm 16.54 \mathrm{U} / \mathrm{L}$ for cellulase production optimized parameters and $2804.40 \pm 28.5$ and $444.94 \pm 16.25 \mathrm{U} / \mathrm{L}$ for xylanase production optimized parameters, respectively, which were close to the predicted values obtained in the model. The fitness of single optimization models demonstrated an excellent correlation between predicted and experimental data. The verification of multi-response 

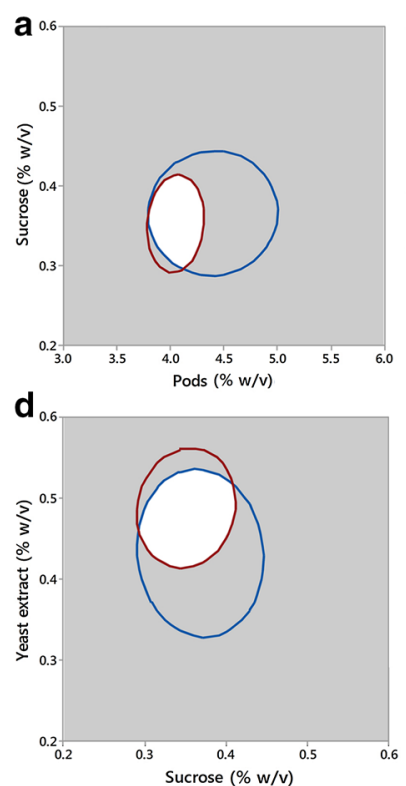

b

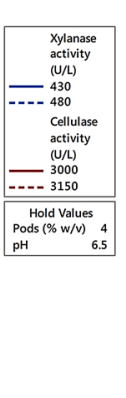

e
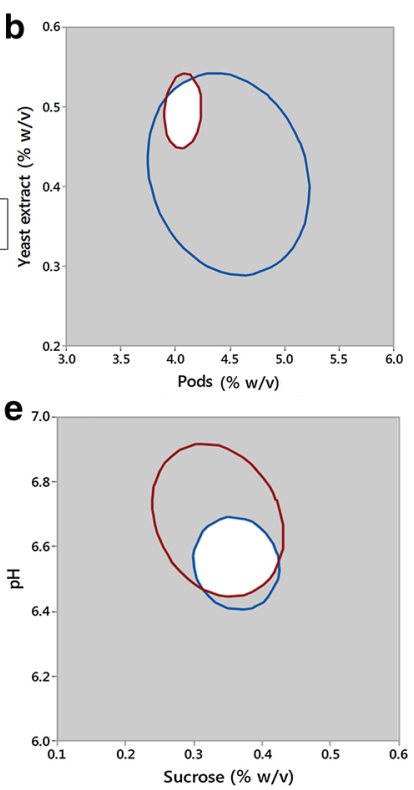
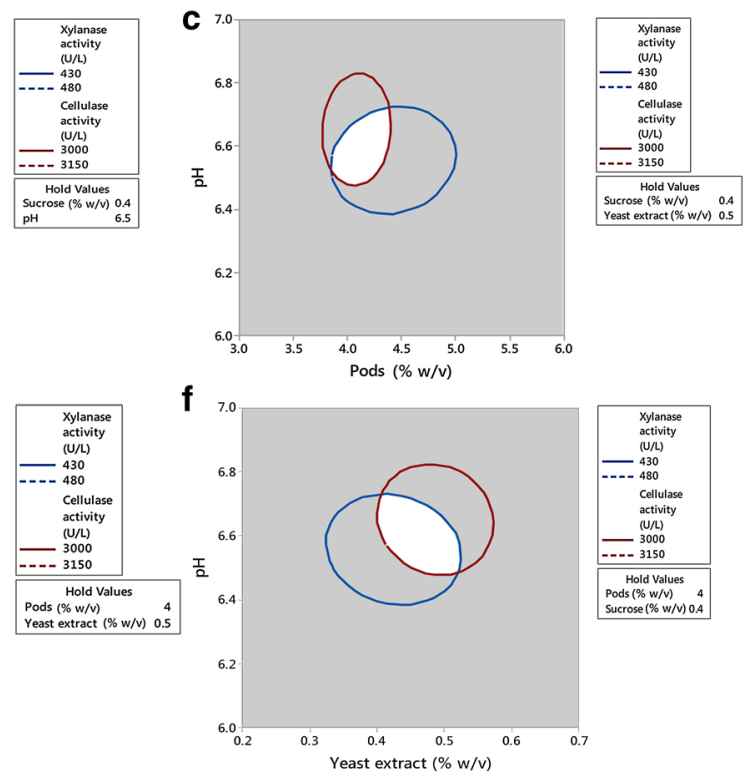

f
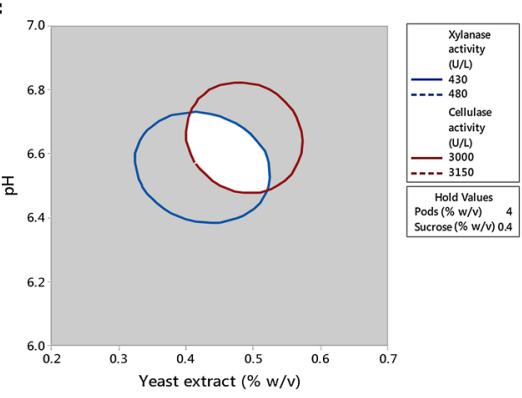

Fig. 6 Contour plot showing the maximum response of third variable as mid-value in each plot with varying variables: a pods vs sucrose, $\mathbf{b}$ pods with yeast extract, $\mathbf{c}$ pods with $\mathrm{pH}, \mathbf{d}$ sucrose with yeast extract, e sucrose with $\mathrm{pH}, \mathbf{f}$ yeast extract with $\mathrm{pH}$

optimization model had shown a high degree of precision of more than $98.5 \%$. Cellulase and xylanase activities from individual and multi-objective optimized medium are summarized in Table 4. Improvement of single and multiresponse optimization approach in comparison with $3 \%$ pods containing medium was observed with 19.88 and $19.02 \%$ with cellulase activity and 33.33 and $31.72 \%$ with xylanase activity correspondingly. The maximum collective responses values at an optimal level were found to be little lower than individual response optimization values. Multi-objective optimization is a more relevant technique than a single response optimization to develop an economic bioprocess which aims multi products.

\section{Conclusion}

Synergistic effect of cellulase and xylanase can be attained for the enhanced lignocellulosic biomass hydrolysis and biofuel production. To make the fermentative production of cellulase and xylanase more economical, the pods of an agricultural weed $P$. juliflora were used as a novel and cheap biomass for the concurrent production of enzymes. High cellulosic content of these pods containing medium facilitated the growth and metabolism of $T$. reesei NCIM 1186 and yielded a significant level of cellulase and xylanase. RSM optimization significantly improved both the cellulase and xylanase observed activities over the 'one factor at a time' optimization results. Further, the multiobjective procedure finds an optimal tradeoff between the production of cellulase and xylanase.
Acknowledgements This work was supported by the Department of Science and Technology (SB/EMEQ-157/2013) India.

\section{Compliance with ethical standards}

Conflict of interests The authors declare that they have no conflict of interests.

Open Access This article is distributed under the terms of the Creative Commons Attribution 4.0 International License (http:// creativecommons.org/licenses/by/4.0/), which permits unrestricted use, distribution, and reproduction in any medium, provided you give appropriate credit to the original author(s) and the source, provide a link to the Creative Commons license, and indicate if changes were made.

\section{References}

Ahamed A, Vermette P (2008) Culture-based strategies to enhance cellulase enzyme production from Trichoderma reesei RUT-C30 in bioreactor culture conditions. Biochem Eng J 40(3):399-407

Ahamed A, Vermette P (2010) Effect of mechanical agitation on the production of cellulases by Trichoderma reesei $\mathrm{RUT}-\mathrm{C} 30$ in a draft-tube airlift bioreactor. Biochem Eng J 49(3):379-387

Bailey MJ, Biely P, Poutanen K (1992) Interlaboratory testing of methods for assay of xylanase activity. J Biotechnol 23(3):257-270

Coffman AM, Li Q, Ju L-K (2014) Effect of Natural and Pretreated Soybean Hulls on Enzyme Production by Trichoderma reesei. J Am Oil Chem Soc 91(8):1331-1338

Domingues F, Queiroz J, Cabral J, Fonseca L (2000) The influence of culture conditions on mycelial structure and cellulase production by Trichoderma reesei Rut C-30. Enzyme Microb Technol 26(5):394-401

Erickson B, Winters P (2012) Perspective on opportunities in industrial biotechnology in renewable chemicals. Biotechnol $\mathrm{J}$ 7(2):176-185 
Esterbauer H, Steiner W, Labudova I, Hermann A, Hayn M (1991) Production of Trichoderma cellulase in laboratory and pilot scale. Bioresour Technol 36(1):51-65

Foreman PK, Brown D, Dankmeyer L, Dean R, Diener S, DunnColeman NS, Goedegebuur F, Houfek TD, England GJ, Kelley AS (2003) Transcriptional regulation of biomass-degrading enzymes in the filamentous fungus Trichoderma reesei. J Biol Chem 278(34):31988-31997

Gautam SP, Bundela PS, Pandey AK, Khan J, Awasthi MK, Sarsaiya $S$ (2011) Optimization for the production of cellulase enzyme from municipal solid waste residue by two novel cellulolytic fungi. Biotechnol Res Int 2011:8. doi:10.4061/2011/810425

Ghose T (1987) Measurement of cellulase activities. Pure Appl Chem 59(2):257-268

Gonçalves GA, Takasugi Y, Jia L, Mori Y, Noda S, Tanaka T, Ichinose H, Kamiya N (2015) Synergistic effect and application of xylanases as accessory enzymes to enhance the hydrolysis of pretreated bagasse. Enzyme Microb Technol 72:16-24

Gupta R, Gigras P, Mohapatra H, Goswami VK, Chauhan B (2003) Microbial $\alpha$-amylases: a biotechnological perspective. Process Biochem 38(11):1599-1616

Häkkinen M, Sivasiddarthan D, Aro N, Saloheimo M, Pakula TM (2015) The effects of extracellular $\mathrm{pH}$ and of the transcriptional regulator PACI on the transcriptome of Trichoderma reesei. Microbial Cell Factor 14(1):1

Jampala P, Murugan P, Ramanujam S, Uppuluri KB (2015) Investigation on the effect of carbon and nitrogen sources for the production of cellulosome by Trichoderma reesei NCIM 1186 using saturated placket burman design. Biosci Biotechnol Res 12:1577-1586

Juhasz T, Szengyel Z, Reczey K, Siika-Aho M, Viikari L (2005) Characterization of cellulases and hemicellulases produced by Trichodermareesei on various carbon sources. Process Biochem 40(11):3519-3525

Jun H, Kieselbach T, Jönsson LJ (2011) Enzyme production by filamentous fungi: analysis of the secretome of Trichoderma reesei grown on unconventional carbon source. Microbial Cell Factor 10(1):1

Kachlishvili E, Penninckx MJ, Tsiklauri N, Elisashvili V (2006) Effect of nitrogen source on lignocellulolytic enzyme production by white-rot basidiomycetes under solid-state cultivation. World J Microbiol Biotechnol 22(4):391-397

Kanaga K, Pandey A, Kumar S (2016) Multi-objective optimization of media nutrients for enhanced production of algae biomass and fatty acid biosynthesis from Chlorella pyrenoidosa NCIM 2738. Bioresour Technol 200:940-950

Kapich A, Prior B, Botha A, Galkin S, Lundell T, Hatakka A (2004) Effect of lignocellulose-containing substrates on production of ligninolytic peroxidases in submerged cultures of Phanerochaete chrysosporium ME-446. Enzyme Microb Technol 34(2):187-195

Liming X, Xueliang S (2004) High-yield cellulase production by Trichoderma reesei $\mathrm{ZU}-02$ on corn cob residue. Bioresour Technol 91(3):259-262

Lo C-M, Zhang Q, Callow NV, Ju L-K (2010) Cellulase production by continuous culture of Trichoderma reesei Rut C30 using acid hydrolysate prepared to retain more oligosaccharides for induction. Bioresour Technol 101(2):717-723

Manivannan A, Narendhirakannan R (2014) Response surface optimization for co-production of cellulase and xylanase enzymes by Trichoderma reesei NRRL-3652. Int J ChemTech Res 6(7):3883

Nochur SV, Roberts MF, Demain AL (1993) True cellulase production by Clostridium thermocellum grown on different carbon sources. Biotechnol Lett 15(6):641-646

Olsson L, Christensen TM, Hansen KP, Palmqvist EA (2003) Influence of the carbon source on production of cellulases, hemicellulases and pectinases by Rut C-30. Enzyme Microb Technol 33(5):612-619

Papavizas G (1985) Trichoderma and Gliocladium: biology, ecology, and potential for biocontrol. Ann Rev Phytopathol 23(1):23-54

Purkarthofer H, Steiner W (1995) Induction of endo- $\beta$-xylanase in the fungus Thermomyces lanuginosus. Enzyme Microb Technol 17(2):114-118

Ramasamy S, Balakrishna HS, Selvaraj U, Uppuluri KB (2014) Production and statistical optimization of oxytetracycline from Streptomyces rimosus NCIM 2213 using a new cellulosic substrate, Prosopis juliflora. BioResources 9(4):7209-7221

Reczey K, Szengyel Z, Eklund R, Zacchi G (1996) Cellulase production by T. reesei. Bioresour Technol 57(1):25-30

Shitanda D, Mukonyi K, Kagiri M, Gichua M, Simiyu L (2014) Properties of Prosopis juliflora and its potential uses in ASAL areas of Kenya. J Agric Sci Technol 15(1)

Srikanth R, Siddartha G, Reddy CHS, Harish B, Ramaiah MJ, Uppuluri KB (2015) Antioxidant and anti-inflammatory levan produced from Acetobacter xylinum NCIM2526 and its statistical optimization. Carbohydr Polym 123:8-16

Strauss J, Kubicek CP (1990) $\beta$-Glucosidase and cellulase formation by a Trichoderma reesei mutant defective in constitutive $\beta$ glucosidase formation. Microbiology 136(7):1321-1326

Sun X, Zhang R, Zhang Y (2004) Production of lignocellulolytic enzymes by Trametes gallica and detection of polysaccharide hydrolase and laccase activities in polyacrylamide gels. J Basic Microbiol 44(3):220-231

Szengyel Z, Zacchi G, Varga A, Réczey K (2000) Cellulase production of Trichoderma reesei Rut C 30 using steampretreated spruce. Twenty-first symposium on biotechnology for fuels and chemicals. Springer, Berlin, pp 679-691

Wen Z, Liao W, Chen S (2005) Production of cellulase by Trichoderma reesei from dairy manure. Bioresour Technol 96(4):491-499

Zhang L, Liu Y, Niu X, Liu Y, Liao W (2012) Effects of acid and alkali treated lignocellulosic materials on cellulase/xylanase production by Trichoderma reesei $\mathrm{Rut}$ C-30 and corresponding enzymatic hydrolysis. Biomass Bioenerg 37:16-24

Zhang L, Wang X, Ruan Z, Liu Y, Niu X, Yue Z, Li Z, Liao W, Liu Y (2014) Fungal cellulase/xylanase production and corresponding hydrolysis using pretreated corn stover as substrates. Appl Biochem Biotechnol 172(2):1045-1054 